bioRxiv preprint doi: https://doi.org/10.1101/212472; this version posted November 1, 2017. The copyright holder for this preprint (which

was not certified by peer review) is the author/funder, who has granted bioRxiv a license to display the preprint in perpetuity. It is made available under aCC-BY-NC-ND 4.0 International license.

\title{
Variation in traction forces during cell cycle progression
}

Benoit Vianay ${ }^{1}$, Fabrice Senger ${ }^{2}$, Simon Alamos ${ }^{3}$, Maya Anjur-Dietrich ${ }^{3}$, Elizabeth Bearce ${ }^{3}$, Bevan

Cheeseman ${ }^{3}$, Lisa Lee ${ }^{3}$, Manuel Théry ${ }^{1,2}$.

1- Univ. Paris Diderot, INSERM, CEA, Hôpital Saint Louis, Institut Universitaire d'Hematologie, UMRS1160, CytoMorpho Lab, 75010 Paris, France.

2- Univ. Grenoble-Alpes, CEA, CNRS, INRA, Biosciences \& Biotechnology Institute of Grenoble, Laboratoire de Phyiologie Cellulaire \& Végétale, CytoMorpho Lab, 38054 Grenoble, France.

3- Physiology Course, Marine Biology Lab, Woods Hole 


\section{Abstract}

Tissue morphogenesis results from the interplay between cell growth and mechanical forces. While the impact of forces on cell proliferation has been fairly well characterized, the inverse relationship is much less understood. Here we investigated how traction forces vary during cell cycle progression. Cell shape was constrained on micropatterned substrates in order to distinguish variations in cell contractility from cell size increase. We performed traction force measurements of asynchronously dividing cells expressing a cell-cycle reporter, to obtain measurements of contractile forces generated during cell division. We found that forces tend to increase as cells progress through G1, before reaching a plateau in S phase, and then decline during G2. This biphasic behaviour revealed a previously undocumented specific and opposite regulation of cell contractility during each cell cycle stage. 


\section{Introduction}

Tissue morphogenesis, during both embryo development and adult tissue renewal, relies on cell growth and shape changes (Thompson, 1942; Lecuit and Lenne, 2007). Tissue growth is mostly supported by cell proliferation. The determination of tissue shape depends on the production of mechanical forces that regulate cell morphology and position (Heisenberg and Bellaïche, 2013). Tissue shape also depends on the spatial regulation of cell differentiation (Heller and Fuchs, 2015; Maitre et al., 2016; Gilmour et al., 2017). Cell mechanics, fate, and growth are far from independent, and the spatio-temporal coordination of growth, differentiation and shape acquisition relies on a tight coupling between the three. It is widely-established that mechanical forces and cell shape direct cell fate and regulate cell cycle progression (Watt et al., 1988; Chen et al., 1997; Ruiz and Chen, 2008; Guilak et al., 2009; Klein et al., 2009; Kilian et al., 2010; Dupont et al., 2011; Chan et al., 2017).

The impact of mechanical forces on cell growth has been the focus of numerous studies, but much less is known about causality in the opposite direction; i.e the effect of cell cycle progression on the production of mechanical forces. Growth factor starvation showed that quiescent cells produce less force than proliferating cells (Rape et al., 2011b). The dynamics of mechanical forces produced across the cell cycle are largely unknown, though studies have nicely-characterized aspects of force production explicitly during mitosis. As cells enter mitosis, they detach from the extra-cellular matrix in a process called deadhesion (Marchesi et al., 2014) resulting in a drastic reduction of tractional forces (Lesman et al., 2014). Mitotic cells continue to produce contractile forces, but they are distributed internally and lead to cell rounding and stiffening (Maddox and Burridge, 2003; Théry and Bornens, 2008). Cells regain the ability to produce traction forces as they exit from mitosis and respread onto the extra-cellular matrix in early G1 (Cramer and Mitchison, 1995; Lesman et al., 2014).

It is not known how traction forces vary from early $G 1$ to late $G 2$. The null hypothesis is that they remain constant, however, the main characteristic of cell cycle progression is cell growth: cell size and mass increase steadily from early G1 to late G2 (Kafri et al., 2013; Son et al., 2015; Varsano et al., 2017). Several works have shown that cell size has a clear influence on the production of traction forces, and that bigger cells tend to produce larger forces (Tan et al., 2003; Reinhart-king et al., 2005; Tolić-Nørrelykke and Wang, 2005; Rape et al., 2011a; Oakes et al., 2014). According to this trend, traction forces should increase steadily with cell cycle progression. We took advantage of a two-week rotation during the Physiology course in Woods Hole to test these hypotheses, and measure the evolution of traction forces during cell cycle progression. 


\section{Results and Discussion}

One straightforward strategy to assess traction forces across the cell cycle would rely on synchronizing cells and performing force production measurements during each cell cycle stage. However synchronizing drugs, which inhibit specific cyclin kinases, blocks DNA replication or disassemble microtubules (Ma and Poon, 2017), can interfere with normal cell cycle progression after release (Bar-Joseph et al., 2008). Rather than pharmacologically perturbing the cell cycle to induce synchronization, we opted to utilize asynchronous cells expressing the fluorescent ubiquitin-based cell cycle indicator (FUCCI) reporter system. The FUCCl reporter is based on the sequential hCdt1mCherry expression in G1 and hGem-Azami Green expression in S/G2/M (Sakaue-Sawano et al., 2008). We worked with RPE-1 cells, a diploid, nontransformed human epithelial cell line, stably expressing the Fucci constructs (Ganem et al., 2014) (Figure 1A). Cells were plated on soft polyacrylamide gel with embedded fiduciary beads, to visualize gel deformation and infer the traction forces produced by the cells, as previously described (Dembo and Wang, 1999) (Figure 1B). It is important to plate cells at low density in order to detect their individual traction force field. However, RPE1 cells are motile in these conditions, and migration is a great source of variability in force production (Meili et al., 2010; Chang et al., 2013; Leal-Egaña et al., 2017). In order to limit these large variations that could blur the changes due to cell cycle progression, cells were plated on adhesive micropatterns, which prevented their motion and normalized their morphology, to achieve a constant and reproducible shape (Singhvi et al., 1994; Théry, 2010). We further considered that standardizing stress fiber position and number would reduce inter-cellular variability (Mandal et al., 2014). We achieved this by plating cells on 60-micron-long and 12-micro-wide dumbell-shaped micropatterns, in which the shape and position of non-adhesive regions dictate the number, size and position of stress fibers (Théry et al., 2006) (Figure C). The combination of these methods: the Fucci reporter, the deformable substrate and the controlled cell shape, allowed us to measure cell cycle position and traction forces in standardized conditions (Figure 1D).

We first confirmed that cells displayed the expected color changes as they progressed in the cell cycle when micropatterned on poly-acrylamide gel (Figure 2). Fibronectin-coated micropatterns were first manufactured on glass coverslips, and then transferred onto a poly-acrylamide hydrogel (Vignaud et al., 2014) (see Methods). RPE1-Fucci cells were plated on micropatterned gels and monitored $24 \mathrm{~h}$ using time-lapse confocal microscopy. As expected, cells expressing exclusively the hCdt1-mCherry (red) construct at the beginning of the cell cycle, reduced it progressively over time, and increased the production of hGem-Azami Green, resulting in the exclusive production of hGemAzami Green approximately 12hrs later, at the end of S phase (Figure 2A). This "green " phase, which corresponded to the G2 phase, lasted about five hours until entry into mitosis (Figure 2A). 
These durations approximately correspond to the cell cycle durations reported for this cell line (Azimzadeh et al., 2009). When the fluorescence signal of each reporter is plotted over time for individual cells, their trajectories follow the typical, dome-like, trend of normal cell cycle progression (Figure 2B, to be compared to Figure 1G in (Sakaue-Sawano et al., 2008)). Similarly, the balance of fluorescence intensities in individual cells at a given time point displayed the same distribution (Figure 2C). Previous characterization of the relationship between fluorescence ratio and cell cycle stage (Sakaue-Sawano et al., 2008) were used to define the boundaries separating the various cell cycle stages (Figure 2B,C). Unfortunately very few cells were detected in the earliest phase of G1 (corresponding to the bottom left corner of the graph, ie absence of hGem-Azami Green and low level of hCdt1-mCherry) since the cell detachment, plating and spreading processes took several hours.

Once the cell cycle stage had been determined by measuring the fluorescence intensities of the two reporters, we imaged the dark-red-fluorescent beads that were embedded in the polyacrylamide gel, to obtain their position while under tension. Cells were then treated with trypsin to disengage the traction forces that were applied on the substrate, and allow relaxation of the fiducial beads. Images of the beads in the presence and absence of cell-mediated tension were processed in order to measure their auto-correlation function and deduce the gel deformation field (Tseng et al., 2012; Martiel et al., 2015) (see Methods). We then used Fourier-transform traction cytometry to estimate the corresponding cell traction force field (Butler et al., 2002; Martiel et al., 2015). (Figure 3A). The force field was further used to calculate the total traction energy produced by each individual cell, to generate the substrate deformation we observed (Butler et al., 2002; Martiel et al., 2015). We then combined the measure of cell cycle position (Figure 2C) and the values of traction energies for each individual cell, to plot the variations of traction forces with respect to cell cycle progression (Figure 3B). To that end, we used cell position along a curvilinear axis representing cell cycle progression in the Fucci reporter graph as a proxy for cycle state (Figure 3B). We observed a biphasic evolution of traction forces. Traction forces first increased from early $\mathrm{G} 1$ to late $\mathrm{G} 1$ and $\mathrm{S}$ phase (Figure 3B). More surprisingly, traction forces then dropped after S phase until G2 (Figure 3B). Cells were further classified with respect to their cycle stage based on the boundaries established previously (Sakaue-Sawano et al., 2008), in order to compare the forces produced in the distinct cell cycle stages. We confirmed that cells entering $\mathrm{S}$ phase produced significantly higher traction forces than cells in early $\mathrm{G} 1$ or late $\mathrm{G} 2$ (Figure $3 \mathrm{C}$ ).

The increase of forces from $\mathrm{G} 1$ to $\mathrm{S}$ is consistent with previous predictions relating cell area and contractility (Tan et al., 2003; Reinhart-king et al., 2005; Tolić-Nørrelykke and Wang, 2005; Rape et al., 2011a; Oakes et al., 2014), based on the fact that cell mass and volume increase from $\mathrm{G} 1$ to $S$ 
phase (San JCB15, Son Varsano CellRep 17). However, in our experimental setting, cell area is predetermined by the micropatterned substrate; effectively uncoupling cell cycle progression from the contact area. Since all cells had the exact same spreading and adhesion areas, the increase in traction forces must reflect a genuine activation of the traction force machinery from early $\mathrm{G} 1$ to $\mathrm{S}$ phase. The force reduction after S phase was unexpected, given that cell mass and volume keep increasing during this period (Kafri et al., 2013; Son et al., 2015; Varsano et al., 2017). These force variations may reflect changes in integrin activation. Indeed, integrins are specifically activated by growth factors during G1 (Walker and Assoian, 2005), so this phase may be more effective in force production. After the G1/S transition, cells are committed to mitosis and their progression is irreversible. In S and G2, cells are no longer sensitive to growth factors. The off-switching of their receptors is likely to impact the integrin activation and be responsible for the reduction in forces that we observed. The mechanism responsible for the force variations we observed deserves further investigation. Additionally, it is important to extend this study on single cells to the tissue level. How do intercellular tensional forces vary during cell cycle progression? How do cells sense the changes in traction and tension in their neighbours? Does it impact their own cell cycle progression in a global mechanical regulation of tissue homeostasis? These important questions will require more than a twoweek practical course in Woods Hole to be addressed but may now be built on this primary study. 


\section{Materials and Methods}

\section{Cell lines}

RPE1-FUCCI (provided by the lab of David Pellman) were grown in a humidified incubator at $37^{\circ} \mathrm{C}$ and $5 \% \mathrm{CO}_{2}$ in DMEM/F12 medium supplemented with $10 \%$ fetal bovine serum and $1 \%$ penicillin/streptomycin. All cell culture products were purchased from GIBCO/Life technologies.

Cells were seeded on patterned gels at 100,000 cells/ $\mathrm{cm}^{2}$. Non-adherent cells were washed away as soon as cells started to attach to the micropatterns. Cells were then allowed to spread fully onto the patterns for 3 hours.

\section{Hydrogel Micropatterning}

Detailed procedure has been described elsewhere for glass micropatterning (Azioune et al., 2010). and gel micropatterning (Vignaud et al., 2014). In brief, glass coverslips were oxidized by oxygen plasma (PDC-100-HP Harrick Plasma) (10 sec, $30 \mathrm{~W}$ ) and incubated for $30 \mathrm{~min}$. with $0.1 \mathrm{mg} / \mathrm{ml}$ PLL-g-PEG (PLL20K-G35-PEG2K, JenKem) in 10mM HEPES pH 7.4. Dried coverslips where then exposed to deep-UV (PSD Pro series NOVASCAN) through a photomask (Toppan) for 4 min. After UV treatment, coverslips were incubated with $10 \mu \mathrm{g} / \mathrm{ml}$ fibronectin (Sigma) and $10 \mu \mathrm{g} / \mathrm{ml}$ Alexa Fluor 546 fibrinogen conjugate (Invitrogen) in 100mM Sodium Bicarbonate buffer, pH=8.4, for 30 min then washed in $100 \mathrm{mM}$ Sodium Bicarbonate buffer, $\mathrm{pH}=8.4$ and finally dried. Acrylamide (8\%) and bisacrylamide solution (0.48\%) (Sigma) was degassed for $30 \mathrm{~min}$, mixed with passivated fluorescent beads by sonication before addition of APS and TEMED. A drop of $25 \mu \mathrm{l}$ of this mix was sandwiched between the micropatterned coverslip and a silanised (acryl-silane) glass coverslip and let to polymerize for $30 \mathrm{~min}$. Gel was allowed to swell in $100 \mathrm{mM}$ sodium bicarbonate buffer and gently removed. Coverslip were rinced with PBS before cell plating.

The Young-modulus of the gels was estimated around $40 \mathrm{kPa}$ given the relative amounts of acrylamide and bis-acrylamide (Tse and Engler, 2010).

\section{Bead Passivation}

50 $\mu$ l fluorescent beads (Fluorosphere \#8810, Invitrogen) are incubated in $1 \mathrm{ml} \mathrm{PLL-Peg} \mathrm{(0.1}$ mg. $\mathrm{ml}^{-1}$ ) for $1 \mathrm{H}$ at $4^{\circ} \mathrm{C}$. Beads were washed 3 times in $10 \mathrm{mM}$ HEPES $\mathrm{pH} 7.4$ and resuspended in 150 $\mu \mathrm{l}$ washing buffer. 10 to $15 \mu \mathrm{l}$ were added to the acrylamide gel before polymerization. 


\section{Imaging}

Live microscopy was performed on Zeiss Cell Observer Z inverted microscopes with Hamamatsu Orca flash 4.0 cameras. Fucci nuclei in time and force measurement experiments were aquired respectively with a 40x (NA=1.2) and a 63x Plan Apo (NA=1.4) objectives.

Nuclei normalized colors, $\mathrm{Rn}$ and $\mathrm{Gn}$, were obtained by measuring each fluorescence intensity in a $5 \mu \mathrm{m}$ diameter circle manually located in the brightest part of the cell nucleus; then divided by its respective background, measured from a $5 \mu \mathrm{m}$ diameter circle manually located far from the cell.

\section{Traction Force Microscopy}

We used the ImageJ plugin and followed the procedure previously described (Martiel et al., 2015). Displacement fields were obtained from bead images taken before and after removal of cells by trypsin treatment. Images were first aligned to correct for experimental drift then cropped to produce 1000 px X 1000 px images. Displacement field was calculated by particle imaging velocimetry (PIV) on the base of normalized cross-correlation following an iterative scheme. Final grid size was $1.65 \mu \mathrm{m} \times 1.65 \mu \mathrm{m}$. Erroneous vectors where discarded owing to their low correlation value and replaced by the median value of the neighbouring vectors. Traction-force field was subsequently estimated by Fourier Transform Traction Cytometry, with a regularization parameter set to $9 \times 10^{-10}$. The mechanical energy was calculated by summing the dot products of displacement with the force times the grid area: $2.72 \mu \mathrm{m}^{2}$. 
bioRxiv preprint doi: https://doi.org/10.1101/212472; this version posted November 1, 2017. The copyright holder for this preprint (which

was not certified by peer review) is the author/funder, who has granted bioRxiv a license to display the preprint in perpetuity. It is made available under aCC-BY-NC-ND 4.0 International license.

\section{Acknowledgements}

We thank the Physiology course directors Jennifer Lippincott-Schwartz, Wallace Marshall and Rob Phillips for inviting all of us to the Marine Biology Laboratory in Woods Hole. We also thank them for their great support, thoughtful advice and remarkably good and motivating intuitions. We are very grateful to Carolyn Ott, Adam Catching and Steve Wilbert who were more than helpful both day and night, during these two weeks. We thank Neil Ganem and David Pellman for providing us the RPE1Fucci cell line. 
bioRxiv preprint doi: https://doi.org/10.1101/212472; this version posted November 1, 2017. The copyright holder for this preprint (which was not certified by peer review) is the author/funder, who has granted bioRxiv a license to display the preprint in perpetuity. It is made available under aCC-BY-NC-ND 4.0 International license.

\section{Figures}

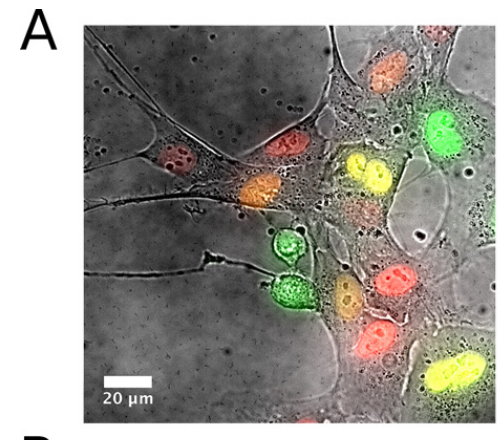

B

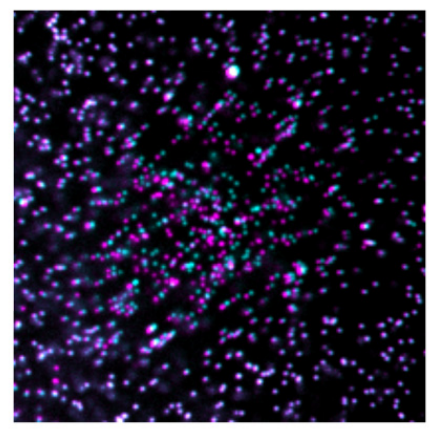

C

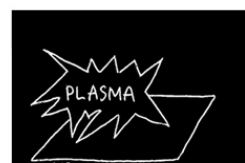

GLASS SLIDE
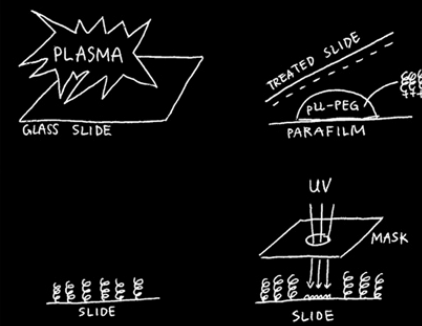

$\frac{\xi \xi \xi \xi \xi \xi}{\text { SLIDE }}$

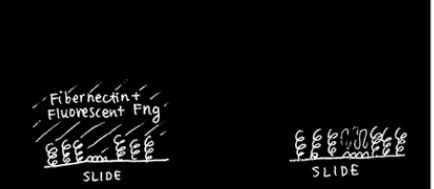

6气

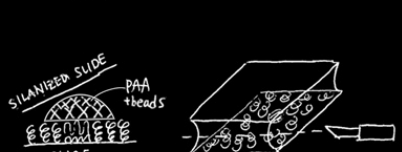
घद्धती $\frac{\operatorname{secomat}}{S L I 0 E}$ 1959 पर

Protein $\log _{2}$ $x \times x \times x \times x$
$x \times A+b e a d$ $x \times A$
$x \times x \times x \times x$ SILANIZEDS SUDE

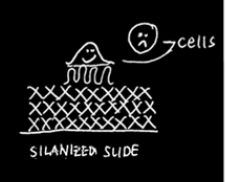

D

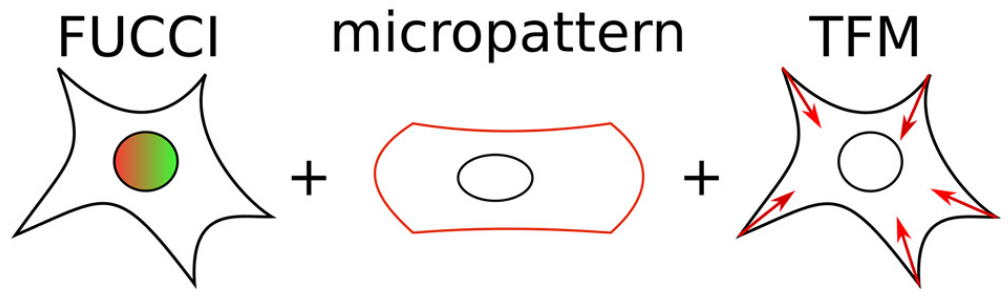

Figure 1: Experimental set up
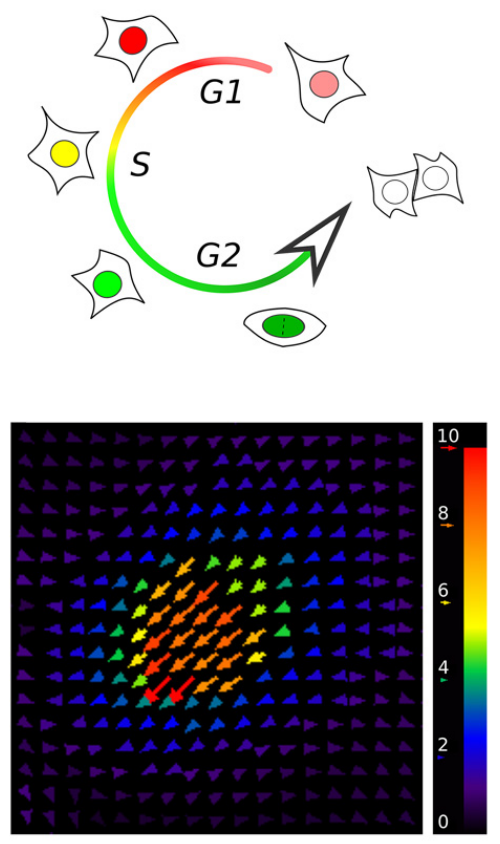

A) Left: RPE1 FUCCl cells spread on PAA gels homogeneously coated with fibronectin. The color of the nucleus indicates its cycle phase. Right: Nucleus color changes during cell cycle progression.

B) Left: Typical images of the beads displacements due to cell traction forces (magenta) compared to beads with no stress (cyan). Right: PIV results of the image on the left with the corresponding beads displacement field.

Displacement scale bar is in pixels.
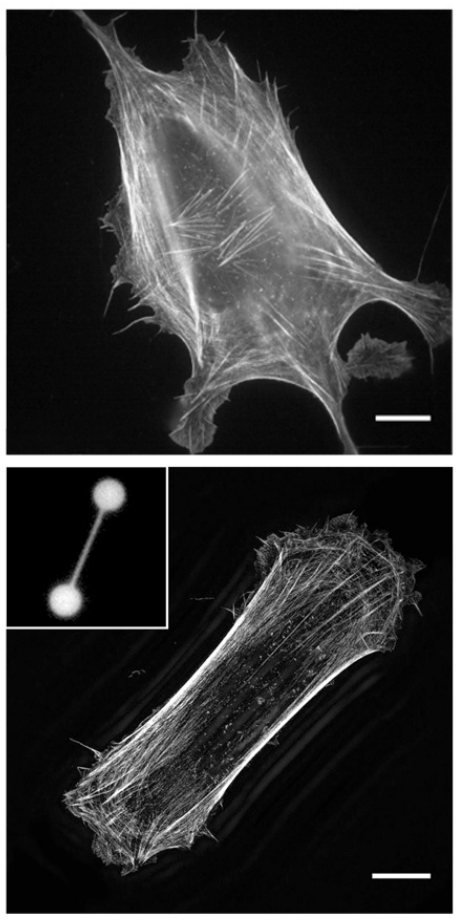

C) Left: Procedure to fabricate micropatterns on PAA gels. 1st row: glass pegylation after plasma activation; 2 nd row: DeepUV illumination; 3rd row: protein incubation; 4th row: PAA gel polymerisation and separation; 5th row: resulting protein micropatterns on PAA gel and cell seeding (see Material and Methods). Right: RPE1 cell spread on homogeneous fibronectin coated glass substrate (top), or on fibronectin patterned glass substrate (bottom) where actin stress fibers are well defined at the two edges due to dumbbell pattern (inset). These two images were acquired by the DeltaVision OMX SR (GE Healthcare).

D) Experimental set up based on $\mathrm{FUCCl}$ cells spread on micro patterned PAA gels to measure cell traction forces during cell cycle progression. 

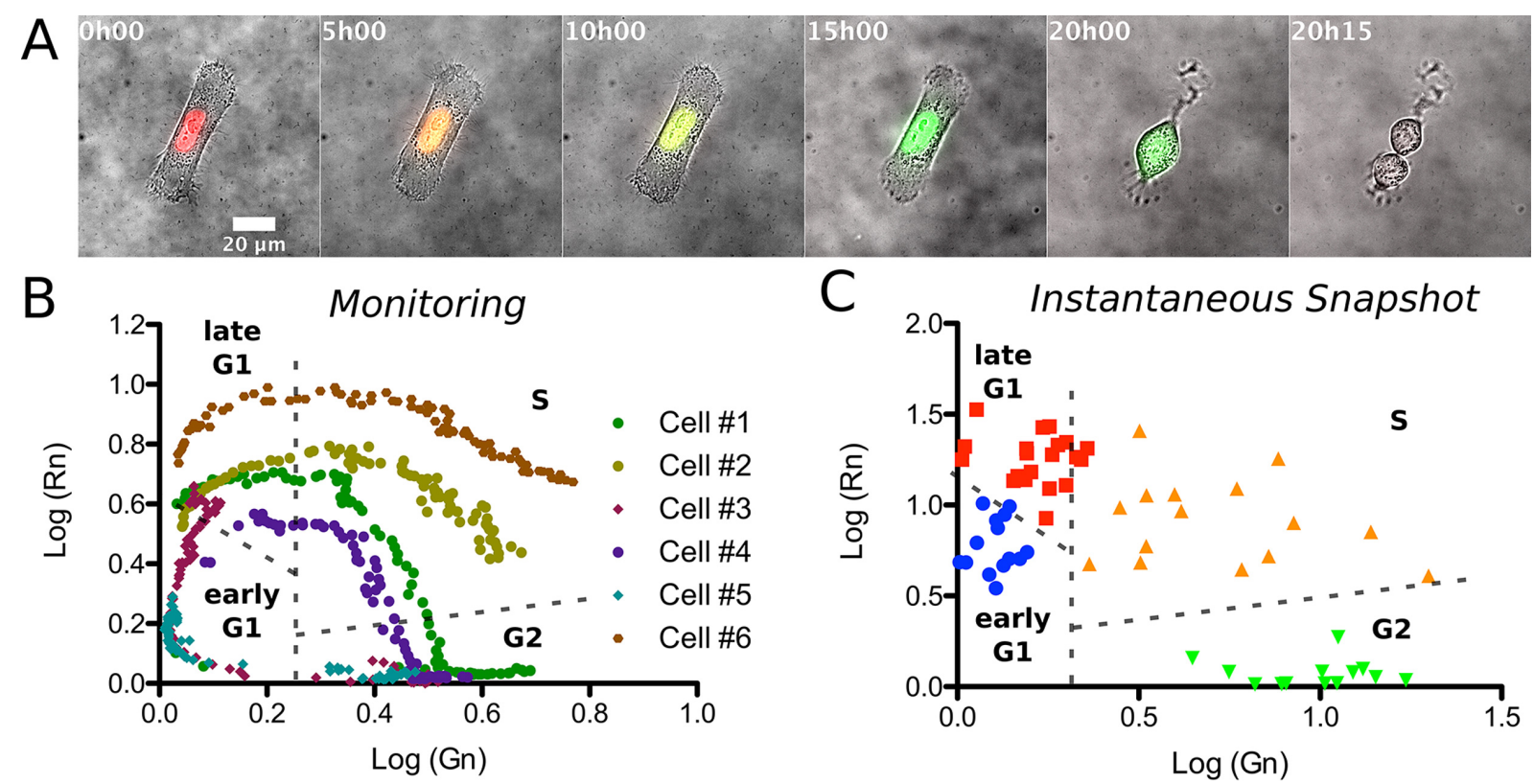

B

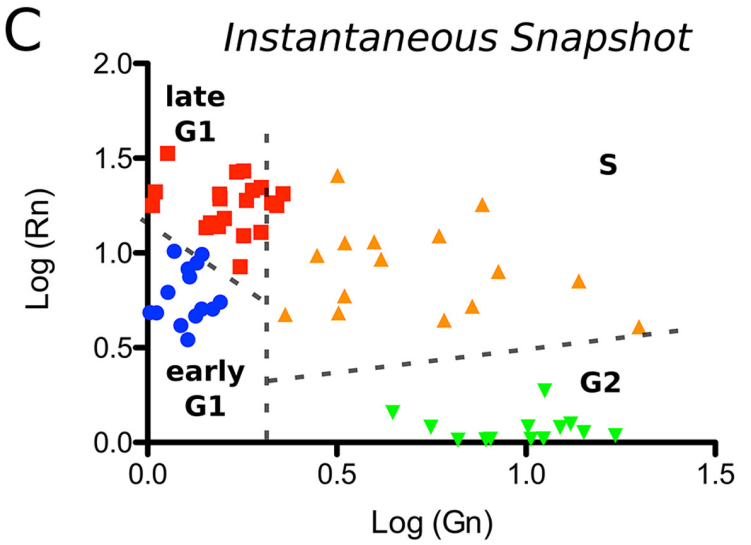

\section{Figure 2: Determining cell cycle progression}

A) Timelapse phase with red and green fluorescence combined images of a RPE1 FUCCl cell spread on a dumbbell pattern on PAA gels over 20 hours. The nucleus color changes confirm the cell cycle progression from G1 - S - G2 until mitosis at $20 \mathrm{~h} 15$ after monitoring.

B) Log-log diagram of the nuclei normalized red color in function of the nuclei normalized green color for 6 different cells monitored over 20 hours during cycle progression. The dashed lines are guides to separate cycle phases (early G1, late G1, S and G2 phases). Diamonds correspond to mitotic cells (G2 - M - G1) during monitoring whereas circles correspond to cells progressing from G1 to G2. The green circles (cell \#1) corresponds to the cell in A).

C) Same log-log diagram of the nuclei normalized color than in B), each point represent a cell ( $N=3$ independant experiments). The colors correspond to the different cycle phases defined by the dashed lines in B). 


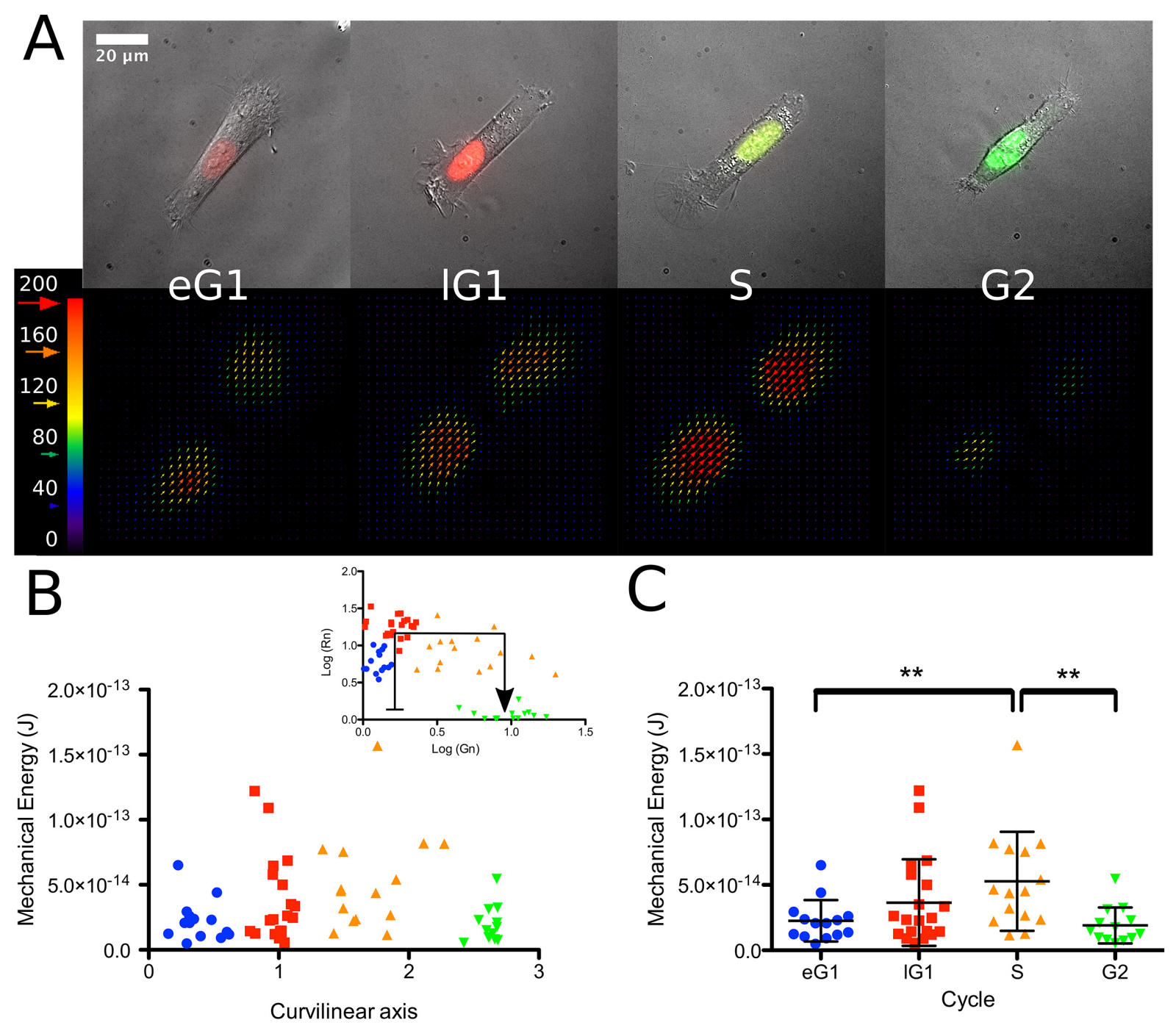

\section{Figure 3: Traction forces variation during cell cycle progression}

A) Phase with red and green fluorescence combined images (top row) of representative instantaneous snapshots of cells at early $\mathrm{G} 1$, late $\mathrm{G} 1, \mathrm{~S}$ and $\mathrm{G} 2$ phase with their corresponding traction force fields (bottom row). For The grid size is $3.3 \mu \mathrm{m} \times 3.3 \mu \mathrm{m}$ for a clear visualization of traction-force fields.

Force scale bar is in Pascal.

B) Cell mechanical energy along curvilinear axis (black arrow) defined in the log-log diagram of nuclei colors (inset). A clear increase of mechanical energy is observed during the $\mathrm{S}$ phase.

C) Statistics of mechanical energy of early G1, late G1, S and G2 grouped cells extracted from B).

Error bars represent mean values and standard deviations ( ${ }^{\star \star} p<0.01$ ). 


\section{References}

Azimzadeh, J., Hergert, P., Delouvée, A., Euteneuer, U., Formstecher, E., Khodjakov, A., and Bornens, M. (2009). hPOC5 is a centrin-binding protein required for assembly of full-length centrioles. J. Cell Biol. 185, 101-114.

Azioune, A., Carpi, N., Tseng, Q., Théry, M., and Piel, M. (2010). Protein micropatterns: A direct printing protocol using deep UVs. Methods Cell Biol. 97, 133-146.

Bar-Joseph, Z., Siegfried, Z., Brandeis, M., Brors, B., Lu, Y., Eils, R., Dynlacht, B. D., and Simon, I. (2008). Genome-wide transcriptional analysis of the human cell cycle identifies genes differentially regulated in normal and cancer cells. Proc.Natl.Acad.Sci.U.S.A 105, 955-960.

Butler, J. P., Tolić-Nørrelykke, I. M., Fabry, B., and Fredberg, J. J. (2002). Traction fields, moments, and strain energy that cells exert on their surroundings. Am. J. Physiol. Cell Physiol. 282, C595-605.

Chan, C. J., Heisenberg, C., and Hiiragi, T. (2017). Coordination of Morphogenesis and Cell-Fate Specification in Development. Curr. Biol. 27, 1-12.

Chang, S. S., Guo, W., Kim, Y., and Wang, Y. (2013). Guidance of Cell Migration by Substrate Dimension. Biophysj 104, 313-321.

Chen, C. S., Mrksich, M., Huang, S., Whitesides, G. M., and Ingber, D. E. (1997). Geometric Control of Cell Life and Death. Science (80-. ). 276, 1425-1428.

Cramer, L. P., and Mitchison, T. J. (1995). Myosin is involved in postmitotic cell spreading. J. Cell Biol. 131, 179-189.

Dembo, M., and Wang, Y. (1999). Stresses at the Cell-to-Substrate Interface during Locomotion of Fibroblasts. Biophys. J. 76, 2307-2316.

Dupont, S. et al. (2011). Role of YAP / TAZ in mechanotransduction.

Ganem, N. J., Cornils, H., Chiu, S.-Y., O'Rourke, K. P., Arnaud, J., Yimlamai, D., Théry, M., Camargo, F. D., and Pellman, D. (2014). Cytokinesis Failure Triggers Hippo Tumor Suppressor Pathway Activation. Cell 158, 833-848.

Gilmour, D., Rembold, M., and Leptin, M. (2017). From morphogen to morphogenesis and back. Nature 541, 311-320.

Guilak, F., Cohen, D. M., Estes, B. T., Gimble, J. M., Liedtke, W., and Chen, C. S. (2009). Control of stem cell fate by physical interactions with the extracellular matrix. Cell Stem Cell 5, 17-26.

Heisenberg, C.-P., and Bellaïche, Y. (2013). Forces in Tissue Morphogenesis and Patterning. Cell 153, 948-962.

Heller, E., and Fuchs, E. (2015). Tissue patterning and cellular mechanics. J. Cell Biol. 211, 219-231.

Kafri, R., Levy, J., Ginzberg, M. B., Oh, S., Lahav, G., and Kirschner, M. W. (2013). Dynamics extracted from fixed cells reveal feedback linking cell growth to cell cycle. Nature 494, 480-483.

Kilian, K. a, Bugarija, B., Lahn, B. T., and Mrksich, M. (2010). Geometric cues for directing the differentiation of mesenchymal stem cells. Proc. Natl. Acad. Sci. U. S. A. 107, 4872-4877.

Klein, E. a, Yin, L., Kothapalli, D., Castagnino, P., Byfield, F. J., Xu, T., Levental, I., Hawthorne, E., Janmey, P. a, and Assoian, R. K. (2009). Cell-cycle control by physiological matrix elasticity and in vivo tissue stiffening. Curr. Biol. 19, 1511-1518.

Leal-Egaña, A., Letort, G., Martiel, J.-L., Christ, A., Vignaud, T., Roelants, C., Filhol, O., and Théry, M. (2017). The size-speed-force relationship governs migratory cell response to tumorigenic factors. Mol. Biol. Cell, mbc.E16-10-0694.

Lecuit, T., and Lenne, P.-F. (2007). Cell surface mechanics and the control of cell shape, tissue patterns and morphogenesis. Nat. Rev. Mol. Cell Biol. 8, 633-644.

Lesman, A., Notbohm, J., Tirrell, D. A., and Ravichandran, G. (2014). Contractile forces regulate cell division in three-dimensional environments. J. Cell Biol. 205, 155-162.

Ma, H. T., and Poon, R. Y. C. (2017). Synchronization of HeLa Cells. 189-201.

Maddox, A. S., and Burridge, K. (2003). RhoA is required for cortical retraction and rigidity during mitotic cell rounding. J. Cell Biol. 160, 255-265. 
Maitre, J.-L., Turlier, H., Illukkumbura, R., Eismann, B., Niwayama, R., Nédélec, F., and Hiiragi, T. (2016). Asymmetric division of contractile domains couples cell positioning and fate specification. Nature 536, 344-348.

Mandal, K., Wang, I., Vitiello, E., Orellana, L. A. C., and Balland, M. (2014). Cell dipole behaviour revealed by ECM sub-cellular geometry. Nat. Commun.

Marchesi, S., Montani, F., Deflorian, G., D'Antuono, R., Cuomo, A., Bologna, S., Mazzoccoli, C., Bonaldi, T., DiFiore, P. P., and Nicassio, F. (2014). DEPDC1B coordinates de-adhesion events and cell-cycle progression at mitosis. Dev. Cell 31, 420-433.

Martiel, J.-L., Leal, A., Kurzawa, L., Balland, M., Wang, I., Vignaud, T., Tseng, Q., and Théry, M. (2015). Measurement of cell traction forces with ImageJ. Methods Cell Biol. 125, 269-287.

Meili, R., Alonso-Latorre, B., del Alamo, J. C., Firtel, R. A., and Lasheras, J. C. (2010). Myosin II Is Essential for the Spatiotemporal Organization of Traction Forces during Cell Motility. Mol. Biol. Cell 21, 405-417.

Oakes, P. W., Banerjee, S., Marchetti, M. C., and Gardel, M. L. (2014). Geometry Regulates Traction Stresses in Adherent Cells. Biophys. J. 107, 825-833.

Rape, A. D., Guo, W.-H., and Wang, Y.-L. (2011a). The regulation of traction force in relation to cell shape and focal adhesions. Biomaterials 32, 2043-2051.

Rape, A., Guo, W.-H., and Wang, Y.-L. (2011b). Microtubule depolymerization induces traction force increase through two distinct pathways. J. Cell Sci. 124, 4233-4240.

Reinhart-king, C. A., Dembo, M., and Hammer, D. A. (2005). The Dynamics and Mechanics of Endothelial Cell Spreading. Biophys. J. 89, 676-689.

Ruiz, S. A., and Chen, C. S. (2008). Emergence of patterned stem cell differentiation within multicellular structures. Stem Cells 26, 2921-2927.

Sakaue-Sawano, A. et al. (2008). Visualizing Spatiotemporal Dynamics of Multicellular Cell-Cycle Progression. Cell 132, 487-498.

Singhvi, R., Kumar, a, Lopez, G. P., Stephanopoulos, G. N., Wang, D. I., Whitesides, G. M., and Ingber, D. E. (1994). Engineering cell shape and function. Science 264, 696-698.

Son, S., Kang, J. H., Oh, S., Kirschner, M. W., Mitchison, T. J., and Manalis, S. (2015). Resonant microchannel volume and mass measurements show that suspended cells swell during mitosis. J. Cell Biol. 211, 757-763.

Tan, J. L., Tien, J., Pirone, D. M., Gray, D. S., Bhadriraju, K., and Chen, C. S. (2003). Cells lying on a bed of microneedles: an approach to isolate mechanical force. Proc. Natl. Acad. Sci. U. S. A. $100,1484-1489$.

Théry, M. (2010). Micropatterning as a tool to decipher cell morphogenesis and functions. J. Cell Sci. $123,4201-4213$.

Théry, M., and Bornens, M. (2008). Get round and stiff for mitosis. HFSP J. 2, 65-71.

Théry, M., Pépin, A., Dressaire, E., Chen, Y., and Bornens, M. (2006). Cell distribution of stress fibres in response to the geometry of the adhesive environment. Cell Motil. Cytoskeleton 63, 341355.

Thompson, D. W. (1942). On Growth and Form, Cambridge Univ. Press.

Tolić-Nørrelykke, I. M., and Wang, N. (2005). Traction in smooth muscle cells varies with cell spreading. J. Biomech. 38, 1405-1412.

Tse, J. R., and Engler, A. J. (2010). Preparation of hydrogel substrates with tunable mechanical properties. Curr. Protoc. Cell Biol. Chapter 10, Unit 10.16.

Tseng, Q., Duchemin-Pelletier, E., Deshiere, A., Balland, M., Guillou, H., Filhol, O., and Théry, M. (2012). Spatial organization of the extracellular matrix regulates cell-cell junction positioning. Proc. Natl. Acad. Sci. U. S. A. 109, 1506-1511.

Varsano, G., Wang, Y., and Wu, M. (2017). Probing Mammalian Cell Size Homeostasis by ChannelAssisted Cell Reshaping. Cell Rep. 20, 397-410.

Vignaud, T., Ennomani, H., and Théry, M. (2014). Polyacrylamide hydrogel micropatterning. Methods Cell Biol. 120, 93-116. 
bioRxiv preprint doi: https://doi.org/10.1101/212472; this version posted November 1, 2017. The copyright holder for this preprint (which was not certified by peer review) is the author/funder, who has granted bioRxiv a license to display the preprint in perpetuity. It is made available under aCC-BY-NC-ND 4.0 International license.

Walker, J. L., and Assoian, R. K. (2005). Integrin-dependent signal transduction regulating cyclin D1 expression and G1 phase cell cycle progression. Cancer Metastasis Rev 24, 383-393.

Watt, F. M., Jordan, P. W., and O'Neill, C. H. (1988). Cell shape controls terminal differentiation of human epidermal keratinocytes. Proc. Natl. Acad. Sci. U. S. A. 85, 5576-5580. 